\title{
The Effect of Autoclave Sterilization on the Fracture Resistance of ProTaper Rotary Files
}

\author{
Roghanizad $\mathbf{N}^{1}$, Khalilak $Z^{2}$, Vatanpour $\mathbf{M}^{1^{*}}$, Haghi $\mathrm{S}^{3}$, Ali Rezaei $\mathbf{P}^{4}$, Movassagh $Z^{5}$ \\ ${ }^{1}$ Assistant professor, Endodontics Dept, Dental Branch of Tehran, Islamic Azad University, Tehran, Iran \\ ${ }^{2}$ Associated professor, Endodontics Dept, Dental Branch of Tehran, Islamic Azad University, Tehran, Iran. \\ ${ }^{3}$ Resident of Restorative dentistry, Dental school, Shahid Beheshti University of Medical Sciences, Tehran, Iran \\ ${ }^{4}$ Assistant professor, Prosthodontics Dept, Dental school, Shahid Beheshti University of Medical Sciences, Tehran , Iran \\ ${ }^{5}$ Assistant professor, Endodontics Dept, Dental school, Hamedan University of Medical sciences, Hamedan, Iran
}

\begin{tabular}{l}
\hline ARTICLE INFO \\
\hline Article Type \\
Orginal Article \\
\hline Article History \\
Received: March 2016 \\
Accepted: August 2016 \\
ePublished: July 2016 \\
\hline Keywords: \\
Autoclave, \\
Fracture, \\
Nickel Titanium, \\
rotary instrument, \\
ProTaper, \\
Sterilization.
\end{tabular}

\section{ABSTRACT}

Background and Aim: The purpose of this study was to evaluate the effect of autoclave sterilization on the fracture rate of ProTaper instruments (ex vivo).

Methods and Materials: One hundred shaping and finishing ProTaper instruments were used in a crown - down technique for cleaning and shaping the mesial canals of extracted mandibular molars using $5.25 \% \mathrm{NaOCl}$ for irrigation. In the experimental group, 50 files were steam autoclaved before each use. In the control group, the files were not exposed to the sterilization process. The working time was reported for each file. Independent t- test was employed to evaluate the statistical significance of the measured values.

Results: The instruments that underwent the sterilization processes did not show any statistically significant differences in comparison with those of the control group. $(\mathrm{P}>0.12)$

Conclusion: The results of this study showed that sterilization in autoclave in the presence of $\mathrm{NaOCl}$ did not lead to a decrease in survival time of the files.

\footnotetext{
Please cite this paper as:

Roghanizad N, Khalilak Z, Vatanpour M, Haghi S, Alizadeh P, Movassagh Z. The Effect of Autoclave Sterilization on the Fracture Resistance of ProTaper Rotary Files. J Res Dent Maxillofac Sci.2016;1(3):33-37.
} 


\section{Introduction:}

Unexpected fracture of rotary files during root canal preparation is one of the biggest concerns in the process of rotary root canal preparation. ${ }^{(1)}$ Fracture often occurs at the apical one third of the file, making removal of the fractured segment difficult if not impossible, especially in narrow canals. (2) Currently, despite the innovations in file designs and electric gear reduction rotary motors, aiming at reduction of such mishaps, unexpected file fracture remains a problem. The fractured segment causes obstruction in the canal which makes three dimensional cleaning, shaping and obturation impossible. ${ }^{(3)}$ Therefore, failure of treatment, due to failure in fulfilling the biologic aims of root canal therapy can be expected. ${ }^{(3)}$

Recently, many investigations have been done on the effect of sterilization on the fracture rate of NiTi rotary instruments. However, whether any changes occur in physical or cutting efficiency of NiTi rotary instruments after autoclave sterilization remains a question. Platino et al reported that repeated autoclaving does not affect the mechanical properties of some $\mathrm{Ni}-\mathrm{Ti}$ rotary files. ${ }^{(4)}$ An evaluation was made by means of Spectroscope on NiTi alloy surface after numerous sterilization cycles and it was concluded that sterilization at temperature of $121{ }^{\circ} \mathrm{C}$ and pressure of 21 psi could cause some changes in the concentration of Nickel, Titanium, Oxygen and Carbon of the alloy, which was directly proportional to the duration of heating. ${ }^{(5)}$ It seems that the steam produced in autoclave is able to Oxydate the surface of rotary files. ${ }^{(5)}$ The effect of sterilization on NiTi rotary instruments has remained a matter of disagreement. Serene et al reported an increase in number of rotations prior to file fracture following dry heat and autoclave sterilization. ${ }^{(2)}$ On the other hand, Mize et al showed that after sterilization of instruments that had rotated $25 \%, 50 \%$ and $75 \%$ of their mean fatigue life time, no significant difference was evident in their fatigue resistance. ${ }^{(6)}$ Silvaggio and Hick concluded that the sterilization of NiTi rotary instruments, up to ten cycles, did not increase their fracture rate. ${ }^{(7)}$ Viana et al explained that the differences in mechanical properties of endodontic instruments was not significant after five cycles of sterilization. ${ }^{(8)}$ Melo et al showed that after five cycles of sterilization, an obvious increase in fatigue resistance was seen. ${ }^{(9)}$ The aim of this study was to evaluate the effect of autoclave sterilization on the fracture resistance of ProTaper rotary file system.

\section{Materials and Methods:}

One hundred shaping and finishing files of ProTaper rotary instruments (Dentsply Maillefer, Ballagigues, Switzerland) were used in this experimental study. (20 for each instrument size: S1, S2, F1, F2, F3).

Mandibular molars were kept in 5.25\% $\mathrm{NaOCl}$ for one hour. Then the degree of mesial root curvature was determined based on Pruett method. ${ }^{(10)}$ Teeth with weine's class 3 , moderate degree of curvature (15-35 degrees), radius curvature of 7-10 $\mathrm{mm}$ and maximum apical foramen size not more than $0.15 \mathrm{~mm}$ in the mesial root were included in this study. All teeth with canal ramifications, internal /external resorption or any canal configuration were excluded. ${ }^{(8)}$

The access cavity was prepared in all teeth, and the working length was determined based on Kuttler's observational method (11) Aiming at equalizing the working length in all specimens at $16 \mathrm{~mm}$, the rest of the coronal segment was reduced by a diamond disc (D\&Z, Germany). ProTaper instruments, (SX, S1, S2, F1, F2, and F3) were used to prepare the canals.

Then the files were randomly divided into two groups of 50 using random number table. In the first group ( group S: Sterilized), files were entered into the sterilization cycle at temperature of $135^{\circ} \mathrm{C}$ and 15 psi pressure for 30 minutes, and then were used to prepare the canals. In the second group (group NS: non sterilized), 50 files were used to prepare the canals without sterilization.

To eliminate the effect of metal fatigue as a confounding variable ${ }^{(12)}$ in the current study according to the recommendation of other researches, ${ }^{(13)}$ rotational time of each file in each engagement was limited to 5 seconds. ${ }^{(12,13)}$ At this point, files of the group $\mathrm{S}$ were entered into 
the sterilization process for the same time duration prior to preparation of the next canal. In the group NS, files were used in the other canals without sterilization. This process was repeated for all files until they fractured. RC Prep (Premier, USA) was used as lubricating agent and 1 $\mathrm{ml}$ of $\mathrm{NaOCl} 5.25 \%$ was used for irrigation between each filing.

The working time duration and the number of prepared canals were recorded for each file. Due to normal distribution of the samples, independent T-test was used to compare the working time duration of each file between the two groups.

\section{Result:}

In group "S", maximum and minimum working time belonged to $\mathrm{F} 1$ and $\mathrm{S} 1$, respectively. In group "NS", S1 had the shortest working time and S2 showed the maximum working time. (Table 1)

The working time duration was slightly longer in group NS which was not significant $(0.12<\mathrm{P}<0.53)$.

\section{Discussion:}

Increased elasticity, separation and deformation of rotary files still remain as weak points of NiTi rotary instruments. Separation can happen without any macroscopic deformation. Some investigations have revealed that various factors, like sterilization, can affect the fatigue of $\mathrm{NiTi}$ rotary instruments..$^{(7,10,14)}$

Endodontic instruments need to be cleaned and sterilized prior to usage, since the direct contact with blood, saliva and necrotic pulp tissues can lead to cross infection between patients. Sterilization stands for the reduction of all type of microorganisms and spores and autoclave sterilization is accepted as the most efficient method for sterilization. ${ }^{(15)}$
It is evident that no significant changes should happen to physical properties of endodontic instruments. ${ }^{(16)}$ Few studies have worked on the effect of sterilization on mechanical properties like cyclic fatigue, ${ }^{(4)}$ torsional moment ${ }^{\left({ }^{(1)}\right)}$ cutting efficiency and micro hardness of endodontic instruments. ${ }^{(5-8)}$ This study is the first to evaluate the effect of sterilization on the survival time of ProTaper rotary instruments under clinical circumstances, over a thousand canals without limitation of sterilization cycles.

The radius and degree of curvature are the two main points in the root canal anatomy that can influence fatigue life of files. ${ }^{(18)}$ In this study, all canal curvatures were between 15 - 35 degrees with radius of curvature ranging from 7 to $10 \mathrm{~mm}$. The working length was set at $16 \mathrm{~mm}$ for all canals.

In some investigations, metal or resin blocks were used to simulate the canal..$^{(5,6,19,20)}$ These artificial canals tend to wear or break during the procedure. Although these tubes are similar in their structure, the difference between the micro hardness of these blocks and natural canals can justify the different result of the previous studies and the current one. In the current study, extracted teeth were used to simulate natural circumstances. Nair et al stated that sterilization cycles can cause corrosion in files which increases their failure. ${ }^{(21)}$ This finding is not in line with ours. On the other hand, Gutmann et al found that the Number of Cycles to Failure (NCF) in NiTi rotary files increases after autoclave and dry heat sterilization which could be due to rejuvenilization of NiTi alloy. ${ }^{(2)}$ This result also contradicts our finding. We found that sterilization cycles tend to be safe for rotary instruments, as shown in the studies by Silvaggio \& Hicks ${ }^{(7)}$ and Mize

Table 1 -Mean and standard deviation of the number of prepared canals based on file size

\begin{tabular}{|c|c|c|c|c|c|c|}
\hline Groups & S1 & S2 & F1 & F2 & F3 & P. value \\
\hline $\begin{array}{l}\text { Sterilized } \\
\text { S }\end{array}$ & $\begin{array}{l}16 \\
( \pm 4.3)\end{array}$ & $\begin{array}{l}27.20 \\
( \pm 2.3) \\
\end{array}$ & $\begin{array}{l}27.30 \\
( \pm 2) \\
\end{array}$ & $\begin{array}{l}24.80 \\
( \pm 4.3) \\
\end{array}$ & $\begin{array}{l}26.30 \\
( \pm 2.7) \\
\end{array}$ & 0.03 \\
\hline $\begin{array}{l}\text { Non Sterilized } \\
\text { NS }\end{array}$ & $\begin{array}{l}21.30 \\
( \pm 7.3) \\
\end{array}$ & $\begin{array}{l}35 \\
( \pm 8.4) \\
\end{array}$ & $\begin{array}{l}32.44 \\
( \pm 6.2) \\
\end{array}$ & $\begin{array}{l}32.18 \\
( \pm 7.2) \\
\end{array}$ & $\begin{array}{l}33.50 \\
( \pm 8)\end{array}$ & 0.04 \\
\hline P.value & 0.12 & 0.35 & 0.41 & 0.38 & 0.53 & \\
\hline
\end{tabular}


Table 2 - Mean and standard deviation of working time of instruments in the two groups

\begin{tabular}{|c|c|c|c|c|c|c|}
\hline $\begin{array}{l}\text { File type } \\
\text { Groups }\end{array}$ & S1 & $\mathrm{S} 2$ & $\mathrm{~F} 1$ & $\mathrm{~F} 2$ & F3 & P.value \\
\hline $\begin{array}{l}\text { Sterilized } \\
\text { (S) }\end{array}$ & $\begin{array}{l}284 \\
( \pm 68.1)\end{array}$ & $\begin{array}{l}206.50 \\
( \pm 28.4)\end{array}$ & $\begin{array}{l}185.50 \\
( \pm 22.4)\end{array}$ & $\begin{array}{l}183 \\
( \pm 28.8)\end{array}$ & $\begin{array}{l}179.50 \\
( \pm 28.4)\end{array}$ & 0.02 \\
\hline $\begin{array}{l}\text { Non Sterilized } \\
\text { (NS) }\end{array}$ & $\begin{array}{l}287.50 \\
( \pm 71.4)\end{array}$ & $\begin{array}{l}218.50 \\
( \pm 33.7)\end{array}$ & $\begin{array}{l}199.44 \\
( \pm 27.6)\end{array}$ & $\begin{array}{l}186.36 \\
( \pm 93.5)\end{array}$ & $\begin{array}{l}184 \\
( \pm 36.3)\end{array}$ & 0.03 \\
\hline P. Value & 0.06 & 0.07 & 0.07 & 0.06 & 0.06 & \\
\hline
\end{tabular}

et al. ${ }^{(6)}$ Similar with the study by Hilt et al, ${ }^{(22) t h i s}$ investigation showed that nor the number of cycles, neither the sterilization process could affect the torque, hardness and microstructure of NiTi alloy.

Another important finding of the present study is that larger files tend to fracture more often than smaller ones and have shorter fatigue life.

According to our results, although autoclave sterilization could not statistically improve the working time of rotary files, but it had a positive effect on them. It should be mentioned that from metallurgical point of view, the temperature of autoclave sterilization is not high enough to cause significant changes in the structure of alloy. On the other hand, it is important to emphasize that the files can be safely reused after sterilization process.

\section{Conclusion:}

The results of this study showed that autoclave sterilization has no significant effect on the fatigue resistance of Protaper instruments.

\section{Acknowledgement:}

We are thankful to those who helped us in this article including the research center of Islamic Azad University, Dental Branch of Tehran.

\section{References:}

1.Gambarini G. Rationale for the use of low-torque endodontic motors in root canal instrumentation. Endod Dent Traumatol 2000;16(3):95-100.

2.Gutmann JL, Gao Y. Alteration in the inherent metallic and surface properties of nickel-titanium root canal instruments to enhance performance, durability and safety: a focused review. Int Endod J 2012;45(2):11328.

3.Martín B, Zelada G, Varela P, Bahillo JG, Magán F, Ahn S, Rodríguez C. Factors influencing the fracture of nickel-titanium rotary instruments. Int Endod J 2003;36(4):262-6.

4. Plotino G, Costanzo A, Grande NM, Petrovic R, Testarelli L, Gambarini G. Experimental evaluation on the influence of autoclave sterilization on the cyclic fatigue of new nickel-titanium rotary instruments. J Endod 2012;38(2):222-5.

5.Gambarini G, Giansiracusa Rubini A, Sannino G, Di Giorgio G, Piasecki L, Al-Sudani D, et al. Cutting efficiency of nickel-titanium rotary and reciprocating instruments after prolonged use. Odontology 2016;104(1):77-81.

6.Oh SR, Chang SW, Lee Y, Gu Y, Son WJ, Lee W, Baek SH, Bae KS, Choi GW, Lim SM, Kum KY. A comparison of nickel-titanium rotary instruments manufactured using different methods and cross-sectional areas: ability to resist cyclic fatigue. Oral Surg Oral Med Oral Pathol Oral Radiol Endod 2010;109(4):6228.

7.Silvaggio J, Hicks ML.Effect of heat sterilization on the torsional properties of rotary nickel-titanium endodontic files. J Endod 1997;23(12):731-4.

8.Viana AC, Gonzalez BM, Buono VT, Bahia MG. Influence of sterilization on mechanical properties and fatigue resistance of nickel-titanium rotary endodontic instruments. Int Endod J 2006;39(9):709-15.

9.Chaves Craveiro de Melo M1, Guiomar de Azevedo Bahia M, Lopes Buono VT.Fatigue resistance of engine-driven rotary nickel-titanium endodontic instruments. J Endod 2002;28(11):765-9.

10. Pruett JP, Clement DJ, Carnes DL Jr. Cyclic fa- 
tigue testing of nickel-titanium endodontic instruments. J Endod 1997;23(2):77-85.

11. Kuttler S, Garala M, Perez R, Dorn SO. The endodontic cube: a system designed for evaluation of root canal anatomy and canal preparation. J Endod 2001;27(8):533-6.

12. Ullmann CJ, Peters OA.Effect of cyclic fatigue on static fracture loads in ProTaper nickel-titanium rotary instruments. J Endod 2005;31(3):183-6.

13. Javidi M, Zarei M, Vatanpour M. Comparison of canal transportation after preparation by 3 different rotary systems. JIDA 2008; 19(4) :97102.

14. Yared GM, Bou Dagher FE, Machtou P. Influence of rotational speed, torque and operator's proficiency on ProFile failures. Int Endod J 2001;34(1):47-53.

15. Huang DM, Zhou XD.Strategies of endodontic infection control. Hua Xi Kou Qiang Yi Xue Za Zhi 2011;29(3):225-8.

16. Casper RB, Roberts HW, Roberts MD, Himel VT,Bergeron BE.Comparison of autoclaving effects on torsional deformation and fracture resistance of three innovative endodontic file systems. J Endod 2011;37(11):1572-5.

17. King JB, Roberts HW, Bergeron BE, Mayerchak MJ. The effect of autoclaving on torsional moment of two nickel-titanium endodontic files. Int Endod J 2012;45(2):156-61.

18. Grande NM, Plotino G, Pecci R, Bedini R, Malagnino VA, Somma F. Cyclic fatigue resistance and three-dimensional analysis of instruments from two nickel-titanium rotary systems. Int Endod J 2006;39(10):755-63.

19. Chaves Craveiro de Melo M, Guiomar de Azevedo Bahia M, Lopes Buono VT. Fatigue resistance of engine-driven rotary nickel-titanium endodontic instruments. J Endod 2002;28(11):765-9.

20. Inan U, Aydin C, Demirkaya K. Cyclic fatigue resistance of new and used Mtwo rotary nickel-titanium instruments in two different radii of curvature.. Aust Endod J 2011;37(3):105-8.

21. Nair AS, Tilakchand M, Naik BD. The effect of multiple autoclave cycles on the surface of rotary nickel-titanium endodontic files: An in vitro atomic force microscopy investigation. J
Conserv Dent 2015;18(3):218-22.

22. Hilt BR, Cunningham CJ, Shen C, Richards N. Torsional properties of stainless-steel and nickel-titanium files after multiple autoclave sterilizations. J Endod 2000;26(2):76-80. 